Jurnal Health Sains: p-ISSN: 2723-4339 e-ISSN: 2548-1398

Vol. 2, No. 5, Mei 2021

\title{
PENGARUH SIKAP TERHADAP KEPATUHAN PERAWAT PADA PENERAPAN BUDAYA KESELAMATAN PASIEN DI RS MITRA SEJATI
}

\section{Hernawati}

Universitas Sumatera Utara (USU) Medan, Indonesia

Email: misshombing94@gmail.com

\begin{tabular}{l}
\hline ARTIKEL INFO \\
\hline Tanggal diterima: 5 Mei 2021 \\
Tanggal revisi: 15 Mei 2021 \\
Tanggal yang disetujui: $25 \mathrm{Mei}$ \\
2021
\end{tabular}

Keywords:

individual characteristic;

leadership style; compliance

ABSTRACT
The application of a patient safety culture such as reporting and recording patient safety incidents at Mitra Sejati Hospital has not been implemented well since most of its nurses do not comply with the rules such as they do not report the incidence since they think that it is not serious enough and they are afraid of reporting it to the management. The objective of the research was to analyze in the influence of individual characteristics and leadership style on nurses' compliance with patient safety at Mitra Sejati Hospital. The research used explanatory method with cross sectional design. The population was 132 patients, and 57 of them were used as the samples. The data were gathered by using questionnaires and by using multiple linear regression tests at the significance level of $95 \%$. The results showed that there were $64.9 \%$ of nurses who were less obedient in implementing a patient safety culture, while those who were obedient were $15.8 \%$. Individual characteristic variables include attitude $(p=0.041)$ and leadership style variables $(p=0.029)$ have an effect on nurses' compliance with the application of patient safety culture. The dominant variable that has the most influence is leadership style with a coefficient value of $\beta=0.350$, meaning that if the head of the room applies a leadership style it will result in an increase in nurse compliance with the application of patient safety culture by 0.350. The nurse's assessment of the headroom's leadership style that is most preferred is the participatory leadership style. It is recommended that the hospital provide training on patient safety to improve the attitude of nurses in realizing potential events or injuries that are more dangerous to patients, so that each head of the room can be a role model for implementing nurses to comply with a patient safety incident reporting culture.

\section{ABSTRAK}

Penerapan budaya keselamatan pasien seperti melaporkan dan mencatat insiden keselamatan pasien di RS Mitra Sejati masih belum terlaksana dengan baik, dilihat dari kepatuhan perawat yang kurang sadar bahwa insiden yang terjadi tidak perlu dilaporkan karena tidak menimbulkan cedera yang fatal bagi pasien dan adanya rasa takut disalahkan apabila

\begin{tabular}{lllllll}
\hline How to cite: & Hernawati (2021) Pengaruh Sikap terhadap Kepatuhan Perawat pada Penerapan Budaya & \\
& Keselamatan Pasien di & RS & Mitra & Sejati. & Jurnal & Health \\
& https://doi.org/10.46799/jhs.v2i5.160 & & & & \\
& $2723-6927$ & & & & & \\
E-ISSN: & Ridwan Institute & & & & \\
Published by: &
\end{tabular}


melaporkan insiden keselamatan pasien. Penelitian ini bertujuan untuk menganalisis pengaruh karakteristik individu dan gaya kepemimpinan terhadap kepatuhan perawat pada budaya keselamatan pasien di Rumah Sakit Mitra Sejati. Jenis penelitian ini adalah cross sectional dengan pendekatan eksplanatori. Populasi adalah seluruh perawat inap sebanyak 132 orang dengan sampel 57 orang. Pengumpulan data menggunakan kuesioner. Data dianalisis dengan menggunakan uji regresi linier berganda pada batas kemaknaan $95 \%$. Hasil penelitian menunjukkan perawat yang kurang patuh menerapkan budaya keselamatan pasien sebanyak 64,9\%, sedangkan yang patuh sebesar $15,8 \%$. Variabel karakteristik individu meliputi sikap $(\mathrm{p}=0,041)$ dan variabel gaya kepemimpinan $(\mathrm{p}=0,029)$ berpengaruh terhadap kepatuhan perawat pada penerapan budaya keselamatan pasien. Variabel dominan yang paling berpengaruh adalah gaya kepemimpinan dengan nilai koefisien $\beta=0,350$, artinya jika kepala ruang menerapkan gaya kepemimpinan akan mengakibatkan peningkatan kepatuhan perawat pada penerapan budaya keselamatan pasien sebesar 0,350. Penilaian perawat terhadap gaya kepemimpinan kepala ruang yang paling disukai adalah gaya kepemimpnan partisipatif. Disarankan agar rumah sakit memberikan pelatihan tentang keselamatan pasien untuk meningkatkan sikap perawat dalam menyadari potensi kejadian atau cedera yang lebih berbahaya

Kata Kunci:

karakteristik individu; gaya kepemimpinan; kepatuhan

\section{Pendahuluan}

Rumah sakit merupakan salah satu institusi penyedia pelayanan kesehatan perorangan secara paripurna melalui pelayanan rawat jalan, rawat inap dan gawat darurat. Pelayanan kesehatan di rumah sakit harus mampu memanajemen risiko terhadap pasien dan kemampuan untuk belajar dalam menindaklanjuti insiden atau cedera yang terjadi serta dapat menerapkan solusi dalam mengurangi timbulnya risiko insiden keselamatan pasien yang terjadi. Oleh karena itu, melalui akreditasi rumah sakit mutu pelayanan harus diselenggarakan sesuai dengan standar keselamatan pasien yang telah ditetapkan.

Keselamatan pasien saat ini merupakan isu global yang penting untuk segera diatasi ketika pasien mengalami medical error di rumah sakit. Banyaknya laporan tuntutan pasien atas terjadinya medical error pada

pasien menuntut rumah sakit dapat
meningkatkan kualitas mutu pelayanan. Keselamatan pasien adalah sistem yang komplek untuk melaksanakan asuhan pasien yang bersifat nyaman maupun aman guna mengurangi timbulnya risiko cidera yang disebabkan oleh kelalaian tindakan maupun tidak mengambilnya tindakan yang seharusnya tidak dilakukan (Simamora, 2019).

Keselamatan pasien sudah menjadi isu dunia semenjak lembaga Institute of Medicine (IOM) di Amerika Serikat telah menerbitkan laporan angka kematian yang disebabkan Kejadian Tidak Diharapkan (KTD) semakin meningkat pada pasien di ruang rawat inap berkisar sekitar 44.000-98.000 setiap tahunnya

Menurut (Pujilestari et al., 2016) Joint Commission International (JCI) melaporkan beberapa negara terdapat 70 persen kejadian 
kesalahan pengobatan (Organization, 2018) sendiri menyebutkan pemberian tindakan injeksi tanpa alat steril yang berkontribusi 40 persen di seluruh dunia dapat diprediksikan 1,5 juta kematian di USA setiap tahunnya yang disebabkan karena tindakan pemberian injeksi yang tidak aman dilakukan dan di Eropa sendiri mengalami risiko infeksi alat tanpa steril sebanyak 83,5 persen pada pasien dan sekitar 18 persen warga eropa mengaku telah mengalami kesalahan di rumah sakit dan 11 persen telah diresepkan dengan obat yang salah dan menjadi bukti kesalahan tindakan medis yang menunjukkan bahwa 50-72,3 persen merupakan kesalahan tindakan yang disebabkan oleh medis (Organization, 2018).

Kejadian insiden keselamatan pasien juga terjadi di Indonesia, data insiden keselamatan pasien di Indonesia sangatlah minim karena kurangnya budaya untuk melaporkan apabila terjadi insiden keselamatan pasien. Namun, masih banyak kita lihat dimedia masa bahwa banyak terjadi malpraktek di rumah sakit, sehingga hal ini mengindikasikan bahwa masih banyak insiden keselamatan pasien yang terjadi di Indonesia. Menurut laporan Komisi Nasional Keselamatan Pasien (KNKPRS) tahun 2019 jumlah Kejadian Nyaris Cidera (KNC) sebesar 2534 kasus, Kejadian Tidak Cidera (KTD) sebesar 2554 kasus dan Kejadian Tidak Diharapkan (KTD) sebesar 2567 kasus, sedangkan yang menyebabkan kematian sebanyak 243 kasus. Insiden keselamatan pasien banyak terjadi pada kelompok usia produktif yaitu 15-30 tahun sebesar 1125 kasus dan kelompok umur 30-65 tahun sebesar 3821 kasus (Kemenkes RI, 2019). Dari data ini dapat kita lihat bahwa angka insiden keselamatan pasien di Indonesia masih tinggi dan tentu saja ini sangat berpengaruh terhadap keselamatan pasien.

Melihat fenomena terjadinya insiden keselamatan pasien di rumah sakit secara global maupun nasional diharapkan rumah sakit dapat memperbaiki kualitas mutu pelayanan kesehatan. Mutu pelayanan rumah sakit dapat dikatakan efektif apabila sesuai dengan prinsip tata kelola klinik (clinical governance) melalui sistem yang menyeluruh dan terpadu yang dapat dinilai dari berbagai indikator (Simanjuntak et al., 2018).

Permenkes No.11 tahun 2017 pasal 5 menyebutkan bahwa setiap fasilitas pelayanan kesehatan harus menyelenggarakan keselamatan pasien. Penerapan standar keselamatan pasien dapat dilaksanakan melalui budaya keselamatan pasien seperti budaya pelaporan insiden keselamatan pasien yang terjadi, dimana setiap Kejadian Nyaris Cidera (KNC), Kejadian Tidak Diinginkan (KTD) dan Kejadian Potensial Cidera (KPC) segera dilaporkan dan ditindaklanjuti.

Menurut (Tomoaia-Cotisel et al., 2018) budaya keselamatan pasien merupakan suatu pondasi utama dalam menuju keselamatan pasien. Budaya keselamatan pasien merupakan norma, nilai, keyakinan dan kepercayaan yang mendukung dan mempromosikan keselamatan pasien. Budaya keselamatan pasien sangat penting dalam mempengaruhi perilaku organisasi rumah sakit dan menjadi tolak ukur seorang karyawan dalam meningkatkan kinerja.

Budaya keselamatan pasien sebagai prinsip yang dianut oleh rumah sakit juga memengaruhi kepatuhan tenaga kesehatan dalam memberikan pelayanan kesehatan yang mendukung keselamatan pasien serta membuat keselamatan pasien menjadi prioritas tertinggi. Budaya keselamatan yang positif merupakan kepercayaan bahwa setiap kali pasien yang dilayani akan mendapatkan perlindungan dari bahaya (Willmott \& Mould, 2018).

Perawat merupakan petugas paramedis yang paling banyak terdapat di rumah sakit dan bertugas selama 24 jam secara terus menerus melayani pasien. Perawat memiliki peran yang sangat penting dalam meningkatkan keselamatan pasien seperti dalam memberikan informasi kepada pasien 
dan keluarga tentang kemungkinan terjadinya risiko insiden, melaporkan jika terjadinya insiden, dan meningkatkan komunikasi yang efektif dengan pasien, keluarga pasien maupun medis lainnya (Waterson et al., 2014). Menurut (Anker et al., 2018) perawat memainkan peran penting dalam menjaga keselamatan pasien. Sebagai peran advokasi lini paling depan, perawat menjadi inisiator dalam penerapan budaya keselamatan pasien pada tatanan pelayanan kesehatan, terutama di rumah sakit.

Berbagai komponen atau faktor yang dapat berkontribusi terhadap insiden keselamatan pasien pada pelayanan kesehatan diantaranya adalah karakteristik individu penyedia layanan kesehatan dan lingkungan organisasi. Karakteristik individu merupakan faktor pertama yang berdampak langsung pada kepatuhan perawat dalam menerapkan budaya keselamatan pasien. Penelitian (Pagala et al., 2017) menunjukkan bahwa ada hubungan antara pengetahuan perawat dengan kepatuhan perawat dalam melaksanakan SOP resiko pasien jatuh di Rumah Sakit X. Penelitian ini menunjukkan bahwa pengetahuan perawat tentang SOP resiko pasien jatuh yang baik mempunyai peluang 3 kali lebih patuh dalam melaksanakan SOP resiko pasien jatuh dibanding perawat yang memiliki pengetahuan kurang.

Berbagai studi melaporkan bahwa penerapan budaya keselamatan pasien terutama pelaporan insiden belum dilaksanakan secara optimal. Dampak yang ditimbulkan dari budaya keselamatan pasien yang tidak optimal dapat menyebabkan kerugian bagi pasien dan rumah sakit. Dalam membangun budaya keselamatan pasien, peran aktif pemimpin termasuk kepala ruang sebagai penggerak di ruangan yang dipimpin merupakan peran yang sangat penting (Sabri \& Hastono, 2018).

Menurut (Nivalinda et al., 2013) kepemimpinan merupakan suatu fasilitator dalam menciptakan hubungan yang efektif antara sumber daya manusia, manajerial dan waktu dalam tercapainya lingkungan kerja yang kondusif. Semua peranan ini diwujudkan melalui gaya kepemimpinan seorang pemimpin. Sebagian besar asumsi tentang gaya kepemimpinan dapat mencerminkan bahwa seorang pemimpin memiliki proses dalam memengaruhi bawahannya dengan cara memfasilitasi aktivitas, membimbing dan membangun suatu hubungan terhadap suatu kelompok maupun secara personal. Setiap gaya kepemimpinan, teknik berkomunikasi serta kemampuan manajerial sangat perlu diperhatikan dalam menciptakan atmosfer kerja yang baik dan kondusif sebagai salah satu upaya terciptanya budaya pada keselamatan pasien (Mbaloto, 2018).

Pada penelitian (Gunawan et al., 2015) mengemukakan bahwa 50 persen responden pimpinan kepala ruang selalu memberikan hukuman jika melaporkan terjadinya insiden pada keselamatan pasien, itu artinya pimpinan kepala ruang belum mendukung budaya terbuka pada pelaporan insiden keselamatan pasien.

Rumah Sakit Umum (RSU) Mitra Sejati merupakan salah satu rumah sakit swasta kelas B yang sudah terakreditasi dan mempunyai peran dalam upaya pembangunan kesehatan di kota Medan serta melaksanakan kewajiban dalam meningkatkan keselamatan pasien. Berdasarkan data kunjungan Rumah Sakit Mitra Sejati pada tahun 2018 sudah menunjukkan hasil yang baik yaitu 76,7 persen, artinya bahwa secara umum minat masyarakat untuk berobat ke Rumah Sakit Mitra Sejati tergolong tinggi, namun meskipun demikian masih ada permasalahan yang berkaitan dengan pelaksanaan pemberian pelayanan keperawatan khususnya dalam penerapan budaya keselamatan pasien.

Berdasarkan hasil survei awal di RSU Mitra Sejati, insiden keselamatan pasien di rumah sakit pernah terjadi beberapa kali di beberapa ruang rawat inap tetapi medical 
error yang terjadi tidak pernah tercatat secara administrasi dan dilaporkan ke Tim Keselamatan Pasien Rumah Sakit (TKPRS). Beberapa alasan yang disampaikan oleh perawat adalah adanya rasa takut melapor, adanya rasa khawatir apabila insiden yang dilaporkan akan memengaruhi kinerja dan menjelekkan nama sendiri serta menjelekkan nama baik rumah sakit, kurangnya rasa kesadaran diri sendiri dari perawat bahwa insiden yang terjadi merasa tidak perlu dilaporkan karena tidak sampai menimbulkan cidera yang fatal pada pasien, melaporkan insiden keselamatan pasien belum menjadi budaya kerja rumah sakit dan kurangnya panutan kepala ruang dalam melaporkan insdien keselamatan pasien.

Pernyataan ini juga diperkuat oleh sekretaris Tim Komite Keselamatan Pasien Rumah Sakit (TKKPRS) bahwa upaya keselamatan pasien di rumah sakit sudah diterapkan dan formulir pelaporan insiden keselamatan pasien sudah ada namum kepala ruang dan perawat sendiri tidak pernah mencatat dan melaporkan insiden yang terjadi di rumah sakit. Selain itu, sekretaris TKKPRS Mitra Sejati juga menyatakan terkait dengan pihak manajemen rumah sakit kurangnya memberi perhatian apabila terjadi suatu insiden keselamatan pasien seperti kejadian pasien jatuh, Tim Komite Keselamatan Pasien Rumah Sakit hanya sekedar merapatkan hal tersebut tanpa solusi yang terlaksana.

Tujuan penelitian adalah menganalisis karakteristik individu terhadap kepatuhan perawat pada penerapan budaya keselamatan pasien di Rumah Sakit Mitra Sejati, menganalisis gaya kepemimpinan terhadap kepatuhan perawat pada penerapan budaya keselamatan pasien di Rumah Sakit Mitra Sejati

Manfaat bagi peneliti penelitian ini dapat menambah dan membuat wawasan serta pengalaman peneliti dalam hal melakukan analisis terhadap kepatuhan perawat dalam menerapkan budaya keselamatan pasien di rumah sakit.

Manfaat bagi rumah sakit penelitian ini diharapkan dapat memberikan informasi dan masukan kepada manajemen Rumah Sakit Mitra Sejati dan Komite Keselamatan Pasien dalam upaya menurunkan angka insiden keselamatan pasien.

Manfaat bagi peneliti selanjutnya penelitian ini diharapkan dapat menjadi bahan referensi dan bahan pembelajaran mengenai kepatuhan perawat dalam menerapkan budaya keselamatan pasien di rumah sakit.

\section{Metode Penelitian}

Jenis metode penelitian yang digunakan dalam penelitian ini adalah cross sectional dengan pendekatan eksplanatory. Berdasarkan waktu pengamatan, pada penelitian ini variabel independen dan variabel dependen diamati pada satu waktu tertentu (cross sectional). Pendekatan eksplanatory digunakan untuk menguji hipotesis yaitu menganalisis pengaruh karakteristik individu dan gaya kepemimpinan terhadap kepatuhan perawat pada budaya keselamatan pasien di Rumah Sakit Mitra Sejati.

Penelitian ini dilaksanakan di rumah sakit Mitra Sejati Medan, dengan pertimbangan bahwa masih rendahnya budaya pelaporan insiden keselamatan pasien di rumah sakit Mitra Sejati tahun 2018.

Waktu penelitian dimulai dari pengajuan judul, penyusunan proposal, penelitian ke lapangan hingga penyusunan tesis.

Populasi dalam penelitian ini adalah seluruh perawat pelaksana di ruang rawat inap di 7 ruang rawat inap Rumah Sakit Mitra Sejati sebanyak 132 orang.

Penarikan sampel yang dilakukan menggunakan teknik Simple Random Sampling, yaitu teknik penarikan sampel bila populasi mendekati homogeny dan jumlah populasi diketahui 


\section{Hasil dan Pembahasan}

\section{A. Hasil Penelitian}

Rumah Sakit Umum Mitra Sejati pada awalnya merupakan tempat praktek bersama dokter umum, dokter spesialis dan dokter sub spesialis serta dokter jaga 24 jam dan apotik yang beralamat di jalan Jenderal Besar A.H. Nasution No 7 Medan. Sejalan dengan perkembangan dan kemajuan zaman serta teknologi, kemudian tercetus rencana untuk mengembangkan dari praktek dokter bersama menjadi sebuah rumah sakit umum dengan tujuan utama melayani masyarakat khususnya pelayanan kesehatan, maka pada tanggal 10 Oktober 2001 Yayasan Mitra Sejati didirikan berdasarkan akte pendirian No.14 oleh Nur Eny Ginting, Sarjana Hukum, Notaris di Medan. Jenis pelayanan kesehatan yang terdapat di RS mitra sejati ini mencakup pelayanan rawat jalan dan rawat inap. Keseluruhan pelayanan tersebut mencakup pelayanan spesialis dan sub spesialis yaitu pelayanan gigi dan mulut, kesehatan anak, bedah, kebidanan dan penyakit kandungan, fisioterapi, penyakit dalam, penyakit paru, dan saluran pernafasan, penyakit jantung dan pembuluh darah, pelayanan mata, kulit dan kelamin, THT, pelayanan penyakit syaraf, patologi klinik, radiologi, patologi anatomi dan kedokteran jiwa.

Pelayanan rawat inap RS mitra sejati memiliki ruangan dengan kelas yang bervariasi dan ditata secara baik, bersih dan nyaman mulai dari kelas VIP, kelas I, kelas II sampai kelas III. Ruangan rawat inap yang diteliti pada RS mitra sejati terdapat 7 ruangan yaitu: ruangan sakura, ruangan flamboyan, ruangan amarilis, ruangan bougenville, ruangan tulip, ruangan ICU dan ruangan teratai. Setiap ruangan memiliki fasilitas yang cukup memadai dan sesuai dengan standar pelayanan kesehatan.

1. Deskripsi karakteristik individu.

Karakteristik

individu

berhubungan dengan ciri individu yang dapat memengaruhi kegiatan atau aktivitas yang akan dilakukannya untuk mencapai suatu harapan atau keinginan. Karakteristik individu pada penelitian ini terbagi menjadi dua yaitu demografis (umur, jenis kelamin, pendidikan, masa kerja dan status perkawinan) dan psikologis (pengetahuan, sikap dan persepsi).

Umur pada penelitian ini menunjukkan bahwa distribusi umur $<35$ tahun sebanyak 51 orang $(89,5 \%)$. Tingkat pendidikan yang paling besar pada penelitian ini didapati sebanyak 25 orang $(43,9 \%)$ yang memiliki pendidikan D3. Hasil penelitian menunjukkan bahwa jenis kelamin yang paling besar pada penelitan ini adalah perempuan sebanyak 48 orang $(84,2 \%)$. Pengalaman kerja selama 1-5 tahun sebanyak 34 orang $(59,6 \%)$. Berdasarkan status perkawinan yang dimiliki responden yang paling besar adalah jumlah status perkawinan yang belum kawin terdapat sebanyak 32 orang $(56,1 \%)$.

Berdasarkan pengetahuan perawat pelaksana lebih banyak dikategorikan berpengetahuan baik yaitu sebanyak 24 orang $(42,1 \%)$, berpengetahuan sedang yaitu 20 orang $(35,1 \%)$, dan berpengetahuan tidak baik yaitu 13 orang (22,8\%). Berdasarkan sikap perawat pelaksana yang diketahui, responden yang memiliki sikap baik yaitu sebanyak 20 orang $(35,1 \%)$, perawat pelaksana yang memiliki sikap sedang yaitu sebanyak 22 orang $(38,6 \%)$, dan perawat pelaksana yang memiliki sikap tidak baik yaitu 15 orang $(26,3 \%)$. 
Berdasarkan hasil penelitian, persepsi diketahui bahwa perawat pelaksana yang memiliki persepsi baik yaitu sebanyak 15 orang $(26,3 \%)$, perawat pelaksana yang memiliki persepsi yang sedang yaitu sebanyak 25 orang $(43,9 \%)$, dan perawat pelaksana yang memiliki persepsi tidak baik yaitu 17 orang (29,8\%). Hasil pengukuran variabel karakteristik individu dapat di lihat pada tabel berikut.

Tabel 2

\section{Distribusi Karakteristik Individu pada Penerapan Budaya}

Keselamatan Pasien di Rumah Sakit

\section{Mitra Sejati}

\begin{tabular}{|c|c|c|}
\hline $\begin{array}{l}\text { Karakteristik } \\
\text { Individu }\end{array}$ & $\mathrm{N}$ & $\%$ \\
\hline \multicolumn{3}{|l|}{ Umur: } \\
\hline$<35$ tahun & 51 & 89,5 \\
\hline$\geq 35$ tahun & 6 & 10,5 \\
\hline \multicolumn{3}{|l|}{ Pendidikan: } \\
\hline D3 & 25 & 43,9 \\
\hline D4 & 1 & 1,8 \\
\hline S1 & 16 & 28,1 \\
\hline Ners & 15 & 26,3 \\
\hline \multicolumn{3}{|l|}{ Jenis Kelamin: } \\
\hline Laki-Laki & 9 & 15,8 \\
\hline Perempuan & 48 & 84,2 \\
\hline \multicolumn{3}{|l|}{ Lama Bekerja: } \\
\hline$<1$ tahun & 4 & 7,0 \\
\hline $1-5$ tahun & 34 & 59,6 \\
\hline$>5$ tahun & 19 & 33,3 \\
\hline \multicolumn{3}{|l|}{ Status Perkawinan } \\
\hline Kawin & 25 & 43,9 \\
\hline Belum kawin & 32 & 56,1 \\
\hline \multicolumn{3}{|l|}{ Pengetahuan } \\
\hline Baik & 24 & 42,1 \\
\hline Sedang & 20 & 35,1 \\
\hline Tidak Baik & 13 & 22,8 \\
\hline \multicolumn{3}{|l|}{ Sikap } \\
\hline Baik & 20 & 35,1 \\
\hline Sedang & 22 & 38,6 \\
\hline Tidak Baik & 15 & 26,3 \\
\hline \multicolumn{3}{|l|}{ Persepsi } \\
\hline Baik & 15 & 26,3 \\
\hline Sedang & 25 & 43,9 \\
\hline Tidak Baik & $\mathrm{n}$ & $\%$ \\
\hline
\end{tabular}

2. Deskripsi gaya kepemimpinan.

Berdasarkan hasil penelitian gaya kepempinan diketahui bahwa penilaian perawat pelaksana terhadap gaya kepemimpinan kepala ruang yang memiliki gaya kepemimpinan demokratis yaitu sebanyak 15 orang
(26,3\%), kepala ruang yang memiliki gaya kepemimpinan partisipatif yaitu sebanyak 29 orang $(50,9 \%)$, kepala ruang yang memiliki gaya kepemimpinan otoriter yaitu sebanyak 10 orang $(17,5 \%)$ dan kepala ruang yang memiliki gaya kepemimpinan bebas tindak sebanyak 3 orang (5,3\%). Hasil pengukuran variabel gaya kepemimpinan kepala ruang terdiri dari gaya kepemimpinan demokratis, gaya kepemimpinan partisipatif, gaya kepemimpinan otoriter dan gaya kepemimpinan bebas tindak yang disajikan pada tabel berikut ini.

Tabel 3

Distribusi Gaya Kepemimpinan Kepala Ruang pada Penerapan Budaya Keselamatan Pasien di Rumah Sakit Mitra Sejati

\begin{tabular}{c|c|c}
\hline $\begin{array}{c}\text { Gaya } \\
\text { Kepemimpinan }\end{array}$ & $\mathrm{n}$ & $\%$ \\
\hline Demokratis & 15 & 26,3 \\
\hline Partisipatif & 29 & 50,9 \\
\hline Otoriter & 10 & 17,5 \\
\hline Bebas Tindak & 3 & 5,3 \\
\hline Total & 57 & 100.0 \\
\hline
\end{tabular}

3. Deskripsi kepatuhan perawat.

Berdasarkan hasil penelitian, variabel kepatuhan perawat diketahui bahwa lebih banyak perawat pelaksana yang kurang patuh pada penerapan budaya keselamatan pasien yaitu sebanyak 37 orang $(64,9 \%)$, perawat pelaksana yang patuh terhadap budaya keselamatan pasien yaitu sebanyak 9 orang $(15,8 \%)$. Kepatuhan perawat pelaksana dalam menerapkan budaya keselamatan pasien berdasarkan jawaban pernyataan responden pada kuesioner dapat diketahui dari tabel frekuensi sebagaimana dalam tabel berikut: 
Tabel 4

Distribusi Kepatuhan Perawat pada Penerapan Budaya Keselamatan Pasien di Rumah Sakit Mitra Sejati

\begin{tabular}{c|c|c}
\hline $\begin{array}{c}\text { Kepatuhan } \\
\text { Perawat }\end{array}$ & $\mathrm{n}$ & $\%$ \\
\hline Patuh & 9 & 15,8 \\
\hline Kurang Patuh & 37 & 64,9 \\
\hline Tidak Patuh & 11 & 19,3 \\
\hline Total & 57 & 100.0 \\
\hline
\end{tabular}

Tabulasi Silang Antara Variabel Karakteristik Individu dan Gaya Kepemimpinan terhadap Kepatuhan Perawat Pada Penerapan Budaya Keselamatan Pasien di Rumah Sakit Mitra Sejati

Penelitian antara variabel karakteristik individu (umur, jenis kelamin, pendidikan, masa kerja, status perkawinan, pengetahuan, sikap dan persepsi), dan variabel gaya kepemimpinan terhadap kepatuhan perawat pada penerapan budaya keselamatan pasien dilakukan dengan tabung silang.

Tabulasi silang antara karakteristik individu terhadap kepatuhan perawat pada penerapan budaya keselamatan pasien di RS Mitra Sejati. Hasil tabulasi silang antara karakteristik individu yaitu umur, jenis kelamin, pendidikan, lama bekerja, status perkawinan, pengetahuan, sikap dan persepsi terhadap kepatuhan perawat pada penerapan budaya keselamatan pasien di rumah sakit mitra sejati disajikan pada tabel berikut:
Tabel 5

Tabulasi Silang Antara

Karakteristik Individu (Umur, Jenis

Kelamin, Pendidikan, Lama Kerja,

Status Pernikahan, Pengetahuan

Sikap dan Persepsi) terhadap

Kepatuhan Perawat pada Penerapan

Budaya Keselamatan Pasien di Rumah Sakit Mitra Sejati

\begin{tabular}{ccccccccc}
\hline \multirow{2}{*}{ Variabel } & \multicolumn{6}{c}{ Kepatuhan Perawat } \\
\cline { 2 - 8 } & Patuh & \multicolumn{2}{c}{$\begin{array}{c}\text { Kurang } \\
\text { patuh }\end{array}$} & \multicolumn{2}{c}{$\begin{array}{c}\text { Tidak } \\
\text { patuh }\end{array}$} & Total \\
\cline { 2 - 8 } & $\mathrm{n}$ & $\%$ & $\mathrm{n}$ & $\%$ & $\mathrm{~N}$ & $\%$ & $\mathrm{n}$ & $\%$ \\
\hline Umur & & & & & & & & \\
\hline $\begin{array}{c}<35 \\
\text { tahun }\end{array}$ & 31 & 60,8 & 9 & 17.6 & 11 & 21,6 & 31 & 100,0 \\
\hline $\begin{array}{c}>35 \\
\text { tahun }\end{array}$ & 6 & 100,0 & 0 & 0,0 & 0 & 0,0 & 6 & 100,0 \\
\hline
\end{tabular}

\section{B. Pembahasan}

1. Kepatuhan Perawat

Kepatuhan perawat pada penerapan budaya keselamatan pasien menunjukkan hasil yang paling banyak pada kategori kurang patuh. Budaya pencatatan dan pelaporan kejadian cidera akibat kesalahan indentifikasi pasien pada saat memberikan pelayanan keperawatan masih belum terlaksana dengan baik. Hal ini disebabkan karena perawat merasa kejadian cidera yang terjadi tidak menimbulkan resiko yang terlalu berbahaya pada pasien. Berbagai alasan lainnya yaitu adanya rasa takut melaporkan kejadian cidera akibat takut disalahkan. Menurut NPSA dalam (Yulisnawati, 2020) menyatakan bahwa budaya komunikasi terbuka merupakan suatu tempat pembelajaran diskusi yang nyaman antara pemimpin dengan perawat untuk lebih memperbaiki sistem keselamatan pasien dan bukan menjadi tempat mencari kesalahan dari individu untuk mendapatkan hukuman. 
Kepatuhan perawat dalam menerapkan budaya pelaporan insiden keselamatan pasien dapat ditingkatkan melalui semangat dan keinginan dalam melakukan tanggung jawab yang penuh dengan standar prosedur operasional yang telah ditetapkan oleh pihak rumah sakit sehingga dapat menampilkan kinerja yang mengarah pada tujuan keselamatan pasien di rumah sakit untuk mencapai pelayanan yang aman dan nyaman. Menurut Mangkunegara dalam (Nursalam, 2011) prestasi sesungguhnya yang dicapai oleh seseorang dalam melaksanakan tugas yaitu dengan penuh tanggung jawab yang dibebankan atau diberikan kepadanya. Selain itu, hal yang dapat ditingkatkan dalam kepatuhan perawat pada penerapan budaya keselamatan pasien yaitu dukungan kepala ruang, dimana pemimpin harus dapat menjadi role model dalam menjalankan tugas dan tanggung jawab untuk mencapai suatu tujuan keselamatan pasien tersebut dan selalu fokus memperbaiki sistem keselamatan pasien dibandingkan dengan terlalu fokus mencari kesalahan individu. Pemimpin yang baik membangun budaya komunikasi terbuka saat terjadi insiden keselamatan pasien di rumah sakit.

Pada penelitian ini, ada 9 faktor yang diduga memengaruhi kepatuhan perawat pada penerapan budaya keselamatan pasien seperti faktor usia, jenis kelamin, pendidikan, masa kerja, status perkawinan, pengetahuan, sikap, persepsi dan gaya kepemimpinan. Hasil analisis statistik menunjukkan hanya ada 2 variabel yang memberikan pengaruh terhadap kepatuhan perawat pada penerapan budaya keselamatan pasien di Rumah Sakit Mitra Sejati. Dari hasil yang didapatkan dalam penelitian ini, selanjutnya peneliti mencoba membahas permasalahan yang ada dan membandingkan dengan penelitian terdahulu dan teori-teori yang dikemukakan seperti pada uraian berikut.

2. Pengaruh Faktor Umur terhadap Kepatuhan Perawat Pada Penerapan Budaya Keselamatan Pasien di RS Mitra Sejati

Berdasarkan penelitian terhadap 57 orang res" "ponden didapatkan sebagian besar umur perawat di RS Mitra Sejati memiliki umur $<35$ tahun $(89,5 \%)$. Hasil uji regresi linier berganda menunjukkan bahwa secara statistik tidak terdapat pengaruh antara umur dengan kepatuhan perawat pada penerapan budaya keselamatan pasien. Variabel umur tidak diikutkan dalam model multivariat karena $\mathrm{p}$ value $<0,05$. Hal ini sesuai dengan penelitian (Fadriyanti \& Suryarinilsih, 2018) menunjukkan bahwa tidak ada pengaruh umur dengan kepatuhan dalam penerapan sasaran keselamatan pasien. Sesuai pendapat menjelaskan bahwa usia muda lebih dianggap memiliki pengalaman yang minim dan lebih sedikit tidak terampil serta kurang mengikuti ketetapan kebijakan dan alur standar prosedur operasional dalam melaksanakan pelayanan kesehatan. Namun, (Pittet, 2001) menyatakan bahwa semakin tingginya usia seseorang maka semakin mampu seseorang tersebut menunjukkan kematangan jiwa dalam berpikir secara rasional dan semakin bijak dalam mengendalikan emosi dan mau membenahi dirinya. Menurut Robbin dalam (Anugrahwati et al., 2018) mengatakan usia muda merupakan usia yang memiliki tingkat pencapaian produktivitasnya baik. Potensi dan energi yang dimiliki usia muda merupakan motivasi dan semangat 
yang membara dalam peningkatan kinerja seseorang dan etos kerja yang kuat.

3. Pengaruh Faktor Jenis Kelamin terhadap Kepatuhan Perawat pada Penerapan Budaya Keselamatan Pasien di RS Mitra Sejati

Berdasarkan penelitian terhadap 57 orang responden didapatkan sebagian besar jenis kelamin perawat di RS Mitra Sejati berjenis kelamin perempuan $(84,2 \%)$. Hasil uji regresi linier berganda menunjukkan bahwa secara statistik tidak terdapat pengaruh antara jenis kelamin dengan kepatuhan perawat pada penerapan budaya keselamatan pasien. Variabel jenis kelamin tidak diikutkan dalam model multivariat karena $\mathrm{p}$ value $<0,05$. Penelitian ini sesuai dengan penelitian (Harus \& Sutriningsih, 2015) yang menunjukkan hasil penelitian sebagian responden tentang kepatuhan pada budaya keselamatan pasien rumah sakit Panti Waluyo Malang berjenis kelamin perempuan (85\%).

Menurut Robbin dalam (Baker, 2007) menjelaskan bahwa tidak ada perbedaan antara laki-laki dengan perempuan dalam memecahkan masalah, kemampuan untuk belajar, keterampilan analitis dan keinginan kemampuan untuk bekerja. Namun, (Pittet, 2001) menyatakan bahwa seorang pria lebih agresif dalam memiliki suatu pengharapan untuk suskses meskipun perbedaannya sangat kecil dibandingkan dengan wanita.

4. Pengaruh Faktor Pendidikan terhadap Kepatuhan Perawat pada Penerapan Budaya Keselamatan Pasien di RS Mitra Sejati

Berdasarkan penelitian terhadap

57 orang responden didapatkan sebagian besar jenis kelamin perawat di RS Mitra Sejati berpendidikan D3
(43,9\%). Hasil uji regresi linier berganda menunjukkan bahwa secara statistik tidak terdapat pengaruh antara pendidikan dengan kepatuhan perawat pada penerapan budaya keselamatan pasien. Variabel pendidikan tidak diikutkan dalam model multivariat karena $\mathrm{p}$ value $<0,05$. Penelitian ini sejalan dengan (Harus \& Sutriningsih, 2015) yang menunjukkan hasil penelitian seluruh responden tentang kepatuhan perawat pada budaya keselamatan pasien rumah sakit Panti Waluyo Malang berpendidikan D3 keperawatan.

Menurut (Pittet, 2001) kemampuan seseorang dalam melaksanakan pekerjaannya juga dipengaruhi oleh status pendidikan. Seseorang yang memiliki tingkat pendidikan yang lebih tinggi dapat diasumsikan sebagai seseorang yang memiliki keterampilan dan pengetahuan yang baik dalam melaksanakan pekerjaannya.

Menurut (Harus \& Sutriningsih, 2015) pendidikan merupakan proses bimbingan yang diberikan kepada seseorang agar mereka dapat mengerti serta memahami bimbingan yang diberikan. Semakin tinggi tingkat pendidikan seseorang maka tingkat pengetahuan orang tersebut akan semakin tinggi untuk menerima dan memahami suatu informasi. Pendidikan secara umum merupakan segala upaya untuk perencanaan seseorang baik secara individu maupun kelompok sehingga apa yang diharapkan dapat dilakukan oleh pelaku pendidikan (Herpan \& Wardani, 2012).

5. Pengaruh Faktor Lama Kerja terhadap Kepatuhan Perawat Pada Penerapan Budaya Keselamatan Pasien di RS Mitra Sejati 
Berdasarkan penelitian terhadap 57 orang responden didapatkan lama kerja perawat di RS Mitra Sejati sebagian besar rentang waktu 1-5 tahun $(59,6 \%)$. Hasil uji regresi linier berganda menunjukkan bahwa secara statistik tidak terdapat pengaruh antara lama kerja dengan kepatuhan perawat pada penerapan budaya keselamatan pasien. Variabel lama kerja tidak diikutkan dalam model multivariat karena $\mathrm{p}$ value $<0,05$. Penelitian serupa dengan (Harus \& Sutriningsih, 2015) yang menunjukkan hasil penelitian hampir seluruh responden mempunyai pengalaman bekerja di RS Panti Waluyo antara 1-5 tahun. Menurut (Wijaya \& Dewi, 2015) status lama bekerja biasanya dikaitkan dengan pengalaman kerja yang akan menentukan kecakapan yang lebih baik lagi terhadap pekerjaannya. Masa kerja yang bervariasi akan memengaruhi keterampilan dan pengalaman perawat dalam memberikan pelayanan yang aman pada pasien. Perbedaan pengalaman dan keterampilan menyebabkan kemampuan perawat dalam memecahkan masalah juga dapat berbeda (Nivalinda et al., 2013).

Menurut (Pittet, 2001) beberapa penelitian menyimpulkan bahwa seseorang yang memiliki waktu yang lama dalam bekerja, maka semakin patuh seseorang melakukan pekerjaannya. Masa kerja yang lama akan membuat seorang pegawai cenderung lebih merasa betah dalam suatu organisasi atau pekerjaan, hal ini disebabkan diantaranya telah beradaptasi dengan lingkungannya yang cukup lama sehingga seorang pegawai akan merasa lebih nyaman dengan pekerjaannya.

Penelitian (Rahayu et al., 2018) menunjukkan bahwa semakin bertambahnya masa kerja tenaga kesehatan di rumah sakit maka tenaga kesehatan tersebut akan semakin berhati-hati, bijak dalam mengikuti peraturan dan standar operasional prosedur dalam melaksanakan pelayanan kesehatan sehingga terhindar terjadinya insiden keselamatan pasien. Menurut (Setyobudi et al., 2015) masa kerja biasanya dikaitkan dengan waktu mulai bekerja, dimana pengalaman kerja juga menentukan kinerja seseorang. Semakin lama masa kerja maka kecakapan akan lebih baik karena telah menyesuaikan dengan pekerjaannya.

6. Pengaruh Faktor Status Perkawinan terhadap Kepatuhan Perawat Pada Penerapan Budaya Keselamatan Pasien di RS Mitra Sejati

Berdasarkan penelitian terhadap 57 orang responden didapatkan status perkawinan perawat di RS Mitra Sejati sebagian besar belum kawin $(56,1 \%)$. Hasil uji regresi linier berganda menunjukkan bahwa secara statistik tidak terdapat pengaruh antara status perkawinan dengan kepatuhan perawat pada penerapan budaya keselamatan pasien. Variabel status perkawinan tidak diikutkan dalam model multivariat karena $\mathrm{p}$ value $<0,05$. Penelitian ini sesuai dengan penelitian (Nurhandini, 2018) yang menunjukkan tidak adanya hubungan yang signifikan antara status perkawinan dengan tingkat kepatuhan perawat pada kewaspadaan standar keselamatan pasien. Namun, (Rahayu et al., 2018) menjelaskan bahwa terdapat secara signifikan antara status perkawinan terhadap insiden keselamatan pasien. Seseorang yang sudah menikah kadang-kadang memiliki banyak tuntutan pemenuhan dalam rumah tangga sehingga hal ini merupakan 
salah satu penyebab seseorang tidak optimal dalam bekerja.

7. Pengaruh Faktor Pengetahuan terhadap Kepatuhan Perawat Pada Penerapan Budaya Keselamatan Pasien di RS Mitra Sejati

Berdasarkan penelitian terhadap 57 orang responden didapatkan pengetahuan perawat di RS Mitra Sejati sebagian besar kategori baik $(42,1 \%)$. Hasil uji regresi linier berganda menunjukkan bahwa secara statistik tidak terdapat pengaruh antara pengetahuan dengan kepatuhan perawat pada penerapan budaya keselamatan pasien. Variabel pengetahuan diikutkan dalam model multivariat karena $\mathrm{p}$ value $>0,05$. Hal ini sejalan dengan penelitian (Iskandar et al., 2016) yang menunjukkan adanya hubungan pengetahuan dengan kepatuhan perawat dalam dalam melaporkan insiden keselamatan pasien di rumah sakit. Menurut (Pittet, 2001) pengetahuan merupakan segala sesuatu yang diketahui seseorang tentang sesuatu hal yang dapat digunakan untuk menjalani kehidupannya. Seseorang memiliki dasar untuk mencari tahu dan menalaah pengalaman yang dimilikinya.

Terkait dengan konsep manajemen sumber daya manusia, pengetahuan merupakan syarat terpenting dalam perilaku karyawan. Karyawan yang hanya menggunakan pengetahuannya sekedarnya akan semakin tertinggal kinerjanya dibandingkan dengan karyawan yang selalu mengupgrade pengetahuannya yang baru (Setyobudi et al., 2015). Menurut (Astari \& Pambudi, 2018) pengetahuan merupakan kemampuan seseorang yang berada pada kawasan kognitif yang dapat dikembangkan melalui proses pendidikan belajar.

Keterkaitan pengetahuan dengan kepatuhan perawat pada budaya keselamatan pasien dapat dibuktikan dari nilai koefisien $\beta$ variabel sebesar 0,119 yang artinya setiap penurunan pengetahuan perawat pelaksana akan mengakibatkan penurunan kepatuhan perawat pada penerapan budaya keselamatan pasien sebesar -0,119 di RS Mitra Sejati. Pengetahuan yang tinggi belum tentu dapat menjamin perawat pelaksana semakin patuh pada penerapan budaya keselamatan pasien. Menurut (Mubarak et al., 2012) menyatakan bahwa pengetahuan merupakan informasi yang dapat merubah seseorang dalam bertindak, karena pengetahuan menjadi dasar untuk melakukan tindakan yang benar. Semakin tinggi pengetahuan seseorang maka akan semakin baik kinerja seseorang dalam bekerja. Pengetahuan merupakan segala sesuatu hal yang diketahui yang dapat digunakan untuk menjalani kehidupannya.

8. Pengaruh Faktor Sikap terhadap Kepatuhan Perawat Pada Penerapan Budaya Keselamatan Pasien di RS Mitra Sejati.

Berdasarkan penelitian terhadap 57 orang responden didapatkan sikap perawat di RS Mitra Sejati sebagian besar kategori sedang $(38,6 \%)$. Hasil uji regresi linier berganda menunjukkan bahwa secara statistik terdapat pengaruh antara sikap dengan kepatuhan perawat pada penerapan budaya keselamatan pasien. Variabel sikap diikutkan dalam model multivariat karena $p$ value $>0,05$. Hasil penelitian ini serupa dengan penelitian (Fitri \& Yasmin, 2011) yang menunjukkan bahwa sikap mempunyai pengaruh yang besar terhadap 
kepatuhan perawat dalam upaya pengembangan keperawatan yang berorientasi pada budaya keselamatan pasien dan berarah positif. Hasil penelitian Fitri tersebut menjelaskan bahwa sikap perawat terhadap kepatuhan budaya keselamatan pasien merupakan suatu norma yang sudah atau telah disepakati bersama untuk diterapkan di Rumah Sakit.

Menurut (Budihardjo, 2014) sikap merupakan pernyataan evaluatif terhadap suatu objek, peristiwa bahkan orang. Hal ini mencerminkan perasaan seseorang terhadap sesuatu. Sikap budaya keselamatan pasien adalah cara pandang perawat pelaksana terhadap budaya keselamatan pasien. (Setiyajati, 2014) sikap adalah kecenderungan bertindak dari individu terhadap stimulus ataupun objek tertentu. Sikap adalah perasaan positif atau negatif atau keadaan mental seseorang yang selalu disiapkan, dipelajari dan diatur yang dapat memberikan pengaruh khusus pada respon seseorang terhadap objek, keadaan dan orang lain. Sikap dalam memengaruhi perilaku seseorang melalui proses pengambilan keputusan yang beralasan dan hasil pertimbangan tersebut dipengaruhi oleh niat individu tersebut.

Penelitian ini menjelaskan bahwa ada keterkaitan sikap perawat pelaksana terhadap kepatuhan perawat pada penerapan budaya keselamatan pasien. Keterkaitan sikap dengan kepatuhan perawat pada penerapan budaya keselamatan pasien dapat dibuktikan dari nilai koefisien $\beta$ variabel sikap sebesar 0,294 yang artinya semakin baik sikap perawat terhadap pentingnya budaya keselamatan pasien untuk mengurangi terjadinya insiden atau kejadian cedera yang lebih berbahaya maka akan semakin patuh perawat dalam menerapkan budaya keselamatan pasien dalam setiap kegiatan pelayanan asuhan keperawatan sebesar 0,294. Menurut pendapat (Notoatmodjo, 2010) bahwa sikap adalah suatu kesiapan untuk bertindak dan bukan merupakan suatu motif tertentu, dengan kata lain sikap bukanlah suatu kegiatan, namun merupakan salah satu faktor predisposisi terhadap terjadinya perilaku untuk membentuk sikap seseorang.

Pada penelitian ini menjelaskan bahwa sikap terhadap kepatuhan perawat pada penerapan budaya keselamatan pasien adalah kategori sedang. Hal ini disebabkan karena pelaporan insiden keselamatan belum menjadi budaya di rumah sakit, sehingga pencatatan dan pelaporan insiden keselamatan pasien belum menjadi keharusan yang dilakukan pada saat memberikan pelayanan asuhan keperawatan. Menurut (Mbaloto, 2018) sikap merupakan hasil pertimbangan untung dan rugi suatu perilaku, dan sikap itu juga dipengaruhi oleh niat sendiri.

Upaya yang harus dilakukan di masa yang akan mendatang agar perawat yang bersikap baik tentang penerapan budaya keselamatan pasien diperlukan pelatihan tentang budaya keselamatan pasien, kepala ruangan dapat menjadi role model yang selalu berkomitmen dalam mendukung keselamatan pasien untuk membangkitkan sikap positif terhadap pelaporan insiden dan monitoring data bagi perawat yang tidak patuh dalam penerapan budaya keselamatan pasien sebagai bahan evaluasi untuk meningkatkan kinerja perawat di rumah sakit. 
Perawat pelaksana yang bersikap baik terhadap pentingnya penerapan budaya keselamatan pasien dalam melaksanakan aktivitas asuhan keperawatan akan memberikan respon yang baik apabila kepala ruangan tidak terlalu menyalahkan perawat jika terjadi suatu kesalahan atau cedera yang sengaja maupun tidak sengaja dilakukan. Selain itu, upaya lainnya yang dapat dilakukan oleh rumah sakit yaitu memberikan suatu penghargaan kepada perawat apabila mereka patuh melakukan budaya keselamatan pasien seperti pena, buku, pakaian dan sepatu seragam serta menjadikan pelaporan insiden keselamatan pasien sebagai budaya yang harus disepakati. Hal ini sesuai dengan pendapat (Ivancevich, 2007) yang menjelaskan bahwa sikap adalah perilaku penentu yang berhubungan secara spesifik antara perasaan, motivasi dan kepribadian. Sikap merupakan keadaan mental yang menghasilkan respon seseorang terhadap objek, orang lain, dan situasi yang berhubungan yang dapat dipelajari melalui pengalaman. Sikap menentukan pandangan awal seseorang terhadap pekerjaaan dan kesesuaian pekerjaan dengan organisasi.

\section{Kesimpulan}

Berdasarkan hasil penelitian dan pembahasan yang telah diuraikan sebelumnya, maka dapat diambil beberapa kesimpulan yang pertama sebanyak 60,8 persen responden memiliki umur $<35$ tahun, jenis kelamin responden yang paling banyak adalah jenis kelamin perempuan sebesar 66,7 persen, tingkat pendidikan yang paling besar yaitu pendidikan D3 sebanyak 68,0 persen, lama kerja responden dengan rentang waktu 1-5 tahun didapati sebesar 58,8 persen, status perkawinan responden belum kawin sebesar
72,0 persen, pengetahuan responden dengan kategori baik sebanyak 91,7 persen, sikap responden dengan kategori sedang didapati sebanyak 31,8 persen dan persepsi responden dengan kategori sedang didapati sebesar 48,0 persen. Kedua sebanyak 50,9 persen penilaian perawat terhadap gaya kepemimpinan kepala ruangan yang paling disukai adalah gaya kepemimpinan partisipatif. Ketiga secara statistik hanya variabel sikap dari karakteristik individu yang berpengaruh terhadap kepatuhan perawat pada penerapan budaya keselamatan pasien, sedangkan variabel yang lainnya tidak berpengaruh. Keempat secara statistik variabel gaya kepemimpinan berpengaruh terhadap kepatuhan perawat pada penerapan budaya keselamatan pasien di RS Mitra Sejati. Kelima variabel yang paling dominan dalam memengaruhi kepatuhan perawat pada penerapan budaya keselamatan pasien di RS Mitra Sejati adalah variabel gaya kepemimpinan.

\section{BIBLIOGRAFI}

Anker, S. D., Kirwan, B., Van Veldhuisen, D. J., Filippatos, G., Comin-Colet, J., Ruschitzka, F., Lüscher, T. F., Arutyunov, G. P., Motro, M., \& Mori, C. (2018). Effects Of Ferric Carboxymaltose On Hospitalisations And Mortality Rates In Iron - Deficient Heart Failure Patients: An Individual Patient Data Meta - Analysis. European Journal Of Heart Failure, 20(1), 125133. Google Scholar

Anugrahwati, R., Hadi, M., \& Haryanto, R. (2018). Hubungan Pembuatan Identifikasi Pasien Dengan Pelaksanaan Asuhan Keperawatan Berdasarkan Standar Akreditasi Rumah Sakit Hermina Podomoro Jakarta: Asuhan Keperawatan. Jurnal Ilmiah Keperawatan Altruistik, 1(1), 51-63. Google Scholar 
Astari, U. T., \& Pambudi, A. (2018). Efektivitas Program Keluarga Harapan Di Kecamatanpandak Bantul. Adinegara, 7(5), 692-705. Google Scholar

Baker, S. N. (2007). Oscillatory Interactions Between Sensorimotor Cortex And The Periphery. Current Opinion In Neurobiology, 17(6), 649-655. Google Scholar

Budihardjo, I. R. M. (2014). Panduan Praktis Menyusun Sop. Ras. Google Scholar

Fadriyanti, Y., \& Suryarinilsih, Y. (2018). Hubungan Jam Kerja Dan Karakteristik Perawat Pelaksana Dengan Penerapan Sasaran Keselamatan Pasien Pada Rumah Sakit Di Kota Padang. Menara Ilmu, 12(6). Google Scholar

Fitri, L., \& Yasmin, Y. (2011). Isolasi Dan Pengamatan Morfologi Koloni Bakteri Kitinolitik. Jurnal Biologi Edukasi, 3(2), 20-25. Google Scholar

Gunawan, G., Harijanto, H., \& Harijanto, T. (2015). Analisis Rendahnya Laporan Insiden Keselamatan Pasien Di Rumah Sakit. Jurnal Kedokteran Brawijaya, 28(2), 206-213. Google Scholar

Harus, B. D., \& Sutriningsih, A. (2015). Pengetahuan Perawat Tentang Keselamatan Pasien Dengan Pelaksanaan Prosedur Keselamatan Pasien Rumah Sakit (Kprs) Di Rumah Sakit Panti Waluya Sawahan Malang. Care: Jurnal Ilmiah Ilmu Kesehatan, 3(1), 25-32. Google Scholar

Herpan, H., \& Wardani, Y. (2012). Analisis Kinerja Perawat Dalam Pengendalian Infeksi Nosokomial Di Rsu Pku Muhammadiyah Bantul Yogyakarta. Kes Mas: Jurnal Fakultas Kesehatan Masyarakat Universitas Ahmad Daulan, 6(3), 24846. Google Scholar

Iskandar, H., Wardhani, V., \& Rudijanto, A. (2016). Faktor-Faktor Yang Mempengaruhi Niat Melapor Insiden
Keselamatan Pasien. Jurnal Aplikasi Manajemen, 14(3), 492-498. Google Scholar

Ivancevich, J. M. (2007). Human Resource Management. New York: Mc Grawhill. Google Scholar

Kemenkes Ri, K. R. I. (2019). Pedoman Gizi Seimbang. Stikes Perintis. Google Scholar

Mbaloto, F. R. (2018). Strategic Leadership Kepala Ruangan Dalam Penerapan Budaya Keselamatan Pasien Oleh Perawat Pelaksana Di Rsud Undata Palu. Jurnal Ilmiah Kesehatan, 9(1), 10-16. Google Scholar

Mubarak, A., Bondonno, C. P., Liu, A. H., Considine, M. J., Rich, L., Mas, E., Croft, K. D., \& Hodgson, J. M. (2012). Acute Effects Of Chlorogenic Acid On Nitric Oxide Status, Endothelial Function, And Blood Pressure In Healthy Volunteers: A Randomized Trial. Journal Of Agricultural And Food Chemistry, 60(36), 9130-9136. Google Scholar

Nivalinda, D., Hartini, M. C. I., \& Santoso, A. (2013). Pengaruh Motivasi Perawat Dan Gaya Kepemimpinan Kepala Ruang Terhadap Penerapan Budaya Keselamatan Pasien Oleh Perawat Pelaksana Pada Rumah Sakit Pemerintah Di Semarang. Jurnal Manajemen Keperawatan, 1(2). Google Scholar

Notoatmodjo, S. (2010). Ilmu Perilaku Kesehatan. Penerbit Rineka Cipta. Google Scholar

Nurhandini, A. (2018). Hubungan Karakteristik Dan Supervisi Terhadap Kepatuhan Perawat Pada Kewaspadaan Standar Di Rumah Sakit Umum Madani Medan Tahun 2018. Google Scholar

Nursalam. (2011). Proses Dan Dokumentasi Keperawatan. Jakarta: Salemba Medik. Google Scholar 
Organization, W. H. (2018). Who Expert Consultation On Rabies: Third Report (Vol. 1012). World Health Organization. Google Scholar

Pagala, I., Shaluhiyah, Z., \& Widjasena, B. (2017). Perilaku Kepatuhan Perawat Melaksanakan Sop Terhadap Kejadian Keselamatan Pasien Di Rumah Sakit X Kendari. Jurnal Promosi Kesehatan Indonesia, 12(1), 138-149. Google Scholar

Pittet, D. (2001). Improving Adherence To Hand Hygiene Practice: A Multidisciplinary Approach. Emerging Infectious Diseases, 7(2), 234. Google Scholar

Pujilestari, A., Maidin, A., \& Anggraeni, R. (2016). Budaya Keselamatan Pasien Di Instalasi Rawat Inap Rsup Dr. Wahidin Sudirohusodo Kota Makassar. Media Kesehatan Masyarakat Indonesia, 10(1), 57-64. Google Scholar

Rahayu, S., Sulistiadi, W., \& Trigono, A. (2018). Pengaruh Karakteristik Individu Dan Implementasi Budaya Keselamatan Pasien Terhadap Insiden Keselamatan Pasien Di Rumah Sakit Umum Daerah Banten. Jurnal Manajemen Dan Administrasi Rumah Sakit Indonesia (Marsi), 2(2), 91-114. Google Scholar

Sabri, L., \& Hastono, S. P. (2018). Statistik Kesehatan. Google Scholar

Setiyajati, A. (2014). Pengaruh Pengetahuan Dan Sikap Perawat Terhadap Penerapan Standar Keselamatan Pasien Di Instalasi Perawatan Intensif Rsud Dr. Moewardi. Uns (Sebelas Maret University). Google Scholar

Setyobudi, W. T., Wiryono, S. K., Nasution, R. A., \& Purwanegara, M. S. (2015). Exploring Implicit And Explicit Attitude Toward Saving At Islamic Bank. Journal Of Islamic Marketing. Google Scholar
Simamora, R. H. (2019). Pengaruh Penyuluhan Identifikasi Pasien Dengan Menggunakan Media Audiovisual Terhadap Pengetahuan Pasien Rawat Inap. Jurnal Keperawatan Silampari, 3(1), 342-351. Google Scholar

Simanjuntak, Y., Liang, J.-J., Chen, S.-Y., Li, J.-K., Lee, Y.-L., Wu, H.-C., \& Lin, Y.L. (2018). Ebselen Alleviates Testicular Pathology In Mice With Zika Virus Infection And Prevents Its Sexual Transmission. Plos Pathogens, 14(2), E1006854. Google Scholar

Tomoaia-Cotisel, A., Farrell, T. W., Solberg, L. I., Berry, C. A., Calman, N. S., Cronholm, P. F., Donahue, K. E., Driscoll, D. L., Hauser, D., \& Mcallister, J. W. (2018). Implementation Of Care Management: An Analysis Of Recent Ahrq Research. Medical Care Research And Review, 75(1), 46-65. Google Scholar

Waterson, M. J., Chung, B. Y., Harvanek, Z. M., Ostojic, I., Alcedo, J., \& Pletcher, S. D. (2014). Water Sensor Ppk28 Modulates Drosophila Lifespan And Physiology Through Akh Signaling. Proceedings Of The National Academy Of Sciences, 111(22), 8137-8142. Google Scholar

Wijaya, A. S., \& Dewi, A. (2015). Analisis Budaya Keselamatan Pasien Di Rsu Pku Muhammadiyah, Bantul. Jmmr (Jurnal Medicoeticolegal Dan Manajemen Rumah Sakit), 4(1). Google Scholar

Willmott, J., \& Mould, J. (2018). Health Professionals' Perception Of Patient Safety Culture In Acute Hospitals: An Integrative Review. Australian Health Review, 42(4), 387-394. Google Scholar

Yulisnawati, Y. (2020). Implementasi Simpanan Akad Mudharabah Di Koperasi Serba Usaha Baitul Maal Wattamwil Rahmat Syariah Semen Kediri Perspektif Fatwa Dewan Syariah 
Hernawati

Nasional Majlis Ulama Indonesia. Islam, 1(1). Google Scholar

Bertuah: Jurnal Syariah Dan Ekonomi

\section{Copyright holder:}

Hernawati (2021)

First publication right:

Jurnal Health Sains

This article is licensed under:

(c) (†) (? 